\title{
Analysis of Conflict Management Strategy in Social- Disaster Prone Community
}

\author{
Thriwaty Arsal ${ }^{1, *}$ Puji Hardati ${ }^{2}$ Suroso ${ }^{3}$
}

\author{
${ }^{1,2,3}$ Universitas Negeri Semarang \\ *Corresponding author. Email: thriwaty_arsal@mail.unnes.ac.id
}

\begin{abstract}
Indonesia, as a multicultural society, has many potential conflicts. The potential conflicts can take the form of individual conflicts. Individuals Conflicts can develop into social conflicts in the form of conflicts between religious beliefs, conflicts between villages, and conflicts between ethnic groups which involve all members of the ethnic group. The purpose of the research: analyzing conflict management strategies in multicultural societies. This research used qualitative research. The analysis used was a qualitative analysis taken from the data as a result of in-depth interviews, observations, and documentation. The research location was in Kalirejo Village, Singorojo District, Kendal Regency, which was widely known as a multicultural society that a diversity of religions embraced by the community. The majority of religions embraced by the people of Kalirejo Village are Islam, Hinduism, Christianity, and Catholicism. The results showed that the people of Kalirejo Village maintain religious life harmony by giving mutual respect between religions realized by implementing harmony, cooperation, tolerance, and respect for religious differences.
\end{abstract}

Keywords: Harmonization of Multicultural Communities, Social Conflicts, Social Disasters.

\section{INTRODUCTION}

Conflict and violence are things that are difficult to avoid in the community, hence requiring effort or resolution mechanisms. Conflict resolution itself is one of the mechanisms or efforts to resolve conflicts. Conflict resolution is done so that life can return to normal because its main goal is creating integration in society. Through the process of social integration, a harmonious situation in the community can be built. Conflict always exists in every space and time. It can also happen anywhere and anytime depending on the existence of competition to meet needs. However, conflict and competition are different. Conflict means trying to bring down an opponent, whereas competition has a positive impact. Thus, when people compete, they bring down their opponents without putting down their value and resources.

According to Omisore and Oladosu (2014)[1], the initial recognition of conflict and paying attention to parties to the conflict is very important. Therefore, negotiations between the parties involved are the best way to resolve conflicts. Meanwhile, according to
Olanrewaju et. al. (2017)[2], multiculturalism and differences arose from contradictory values have culminated in various manifestations: civil war, agitation for the creation of a nation, principles of federal character, income allocation, ethnoreligious crisis, rotational presidency, zoning, terrorism, and national conference. The finding showed that there are characteristics that cause the division of social values in Nigeria.

The diversity that exists in Indonesia causes social disasters (social conflicts) inclined to occur. Also, horizontal conflicts in Indonesia tend to be communal in nature. It is difficult to find aggregate data regarding the number of conflicts that occur in Indonesia, especially individual aggregate conflicts data. Furthermore, the existence of horizontal conflict resulted in many things, one of which was the decline in the Democracy Index. Civil liberties and political rights of citizens are one of the main indicators of the decline in the Indonesian Democratic Index. Based on Podes data (BPS, 2018), recorded in the period 2011-2018, the 
number of villages that became a mass conflict area tended to increase, from around 2,500 villages in 2011 to around

2,800 villages in 2014 and around 3,100 villages in 2018. Based on these data, the conflict is homework that is urgent enough to be resolved. Therefore, one strategy proposed for overcoming conflict is conflict management or resolution.

Social integration in the community will be realized if each individual who is in a community group can control the prejudices that exist in the community so that conflict does not occur. Social integration that occurs in multicultural societies, in general, tends to be achieved through conflict resolution to create a harmonious society, such as the community in Kalirejo Village, Singorojo District, Kendal Regency.

\section{RESEARCH METHOD}

The purpose of this research: to discover the strategies for handling conflicts in social disaster-prone communities. The research method used a qualitative approach and analysis of data from the results of indepth interviews, observations, and documentation studies. The location of the research was in Kalirejo Village, Singorojo District, Kendal Regency, which is widely known as a multicultural society with a diversity of religions embraced by the community.

\section{RESULTS AND DISCUSSION}

Based on the analysis of conflicts in Indonesia that have been conducted, the results of the analysis showed that large-scale and mass conflicts such as those that occurred in Ambon, Poso, Sambas, Sampit, Aceh, and others relatively did not occur again. However, lately, the trend of small-scale and sporadic conflicts has increased and spread to almost all regions of Indonesia. The types of conflicts are also very diverse, such as conflicts based on politics, religion, ethnicity, between officials, natural resources, economic resources, routine (brawls, mass judgments, beatings), and others. Out of all various types of conflicts, the most prominent and significantly-increased one are natural resource conflicts and conflicts between religions. These conditions, if not anticipated early, are feared to lead to greater conflict. Besides, conflict resolution in Indonesia tends to be limited to the cessation of violence (the government often only acts as a 'fire brigade') or only in the form of negative peace and does not lead to positive or substantial peace. The basic problems that cause conflicts in the community have not been completely resolved, for example, the problem of marginalization of community groups, segregation between groups, majority-minority issues, problems of indigenous people and migrants, the destruction of cultural spaces, economic access, education and employment, poverty, etc. If these basic problems are not resolved, it can lead to another conflict. A less systematic resolution of a conflict is comparable to a fire extinguisher who only extinguishes fire and waits for the next fire to occur without touching basic issues. Meanwhile, the loss - both property and lives - is undeterminable. For this reason, it is necessary to build a paradigm of conflict resolution in the form of conflict prevention.

\subsection{Potential Conflicts of Multicultural Communities}

Conflicts can be provoked by problems that are very simple to complex. Besides, various conflicts that occur between individuals can develop into a more complex one if the conflict is not immediately addressed as the case in Kalirejo Village with different community structures in terms of livelihood, religion, and economy so that it can lead to various conflicts. However, these conflicts can be minimized or handled with a variety of strategies. One strategy for handling conflicts done by Kalirejo Village is to do conflict resolution/conflict management.

The results of research and observation suggested that Kalirejo Village is one of the multicultural villages with a diversity of religions embraced by the community. Religions embraced by the people of Kalirejo Village include Islam as the majority religion, Hinduism, Christianity, and Catholicism as a minority religion. 


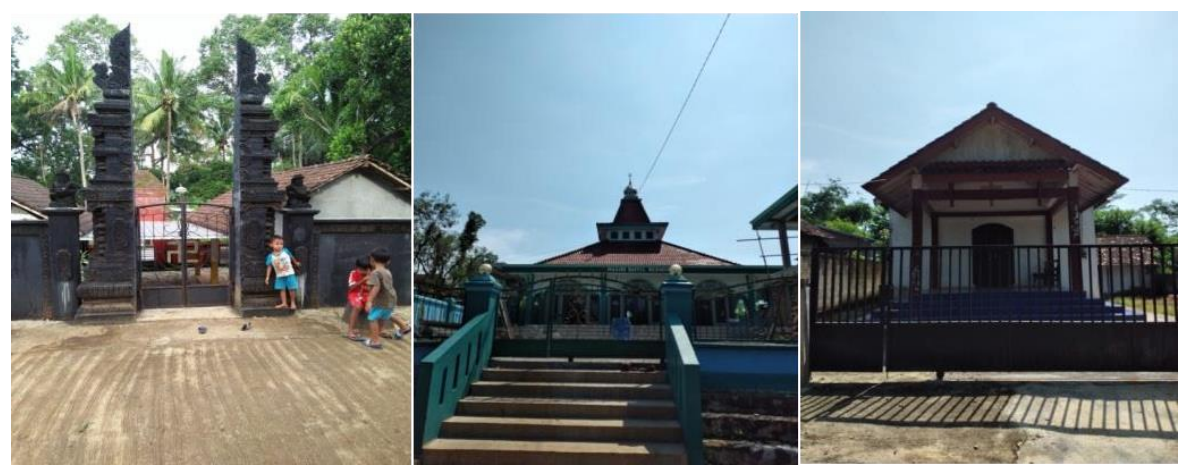

Figure 1. Temple, Mosque and Church in Kalirejo Village

(Documentation of research results, 2020)

Based on the results of an interview with one of the priests namely Mr. Ponijan about conflict management strategies stated that:

"One strategy in anticipating conflict in society is to build social relations between different religious and ethnic communities; carry out activities in the form of social harmony by involving the parties to the conflict to be able to work together, for example building a connecting road between conflicting villages; and managing conflict based on local wisdom."

With this diversity, it certainly can be an opportunity and potential for the emergence of differences that can result in social conflict. According to Suryanto and Aniputra (2012)[3], social capital originating from local wisdom can be used to reduce and anticipate social conflict in Indonesia.

\subsection{The Role and Function of Local Wisdom in Conflict Resolution}

The value of local wisdom that plays a role in managing social conflict in society is an important aspect of bringing up the concept of communication with a non-western perspective (Asian perspective)[3]. The statement further explained that every implementation of local wisdom conducted by the community can present important concepts that can reduce conflict occurrence.

Although conflict may have positive effects, its negative effects must be prevented, especially if the conflict occurs in the form of physical violence that can threaten human lives. Therefore, conflict resolution or conflict management is needed. Conflict management is an effort to prevent conflict from violence without having to achieve problem-solving[5].

Peace-loving society cannot be realized without the roles and influences of religious leaders and officials in Kalirejo Village. Based on the results of an interview with one of the Islamic religious leaders, Mr. Makmur, explained that:

"I, as a religious leader expect good cooperation between residents and religious leaders, local officials, and village youth cadets because, without cooperation between all of them, these local wisdom activities cannot be carried out and continue to be preserved because the people of Kalirejo Village are very upholding high cooperation value. There has never been any force in community participation. This proves that the level of public awareness of conflict management is very high. All communities play an important role in preserving local wisdom in Kalirejo Village, especially religious leaders, community leaders, adolescents, and the village government who are the driving force of conflict management so that the community will always maintain and preserve local wisdom in Kalirejo Village."

This is consistent with the results of research from Zuhdan (2013)[6] regarding community- based conflict management in Malioboro. The research stated that community-based conflict management is conceptualized as a network of local communities that organize themselves based on community values. These community values can be found in every local wisdom conserved by the local community.

Local wisdom can change the mindset and reciprocal relationships of individuals and groups by putting the principle of togetherness above their culture. Thus, it can be said that local wisdom is a form of synthesis of socio-cultural and socio-religious elements whose purpose is to re-bond relationships among people reduced by the struggle for political and economic interests[7].

Like what the Kalirejo Village community did, they consciously continued to carry out local wisdom as 
their identity so that they could continue to maintain harmony and harmony among their citizens. Not only that, harmony between citizens must also be balanced with their behavior towards the balance of nature. So, it can be concluded that with the efforts made in anticipating conflicts that occur in the community through local wisdom and community roles, the conflict can be managed as a whole.

Conflict resolution as stated by Dharmawan (2006)[8], is generally done through two approaches: 1) culture-based or value-oriented conflict resolution; this can be done by utilizing cultural symbols and norms as a unifying party to the conflict, and 2) conflict resolution oriented towards the development of structures or institutions; this can be realized by holding communication forums, empowering public space, and building collective agreements. Meanwhile, the effectiveness of the two conflict resolution approaches aforementioned considers the context and background of the conflict. The context here can be understood as, where the conflict occurs and who is involved in the conflict while the background in question can be interpreted as the origin or cause of the conflict. According to Sriyanto (2007)[9], to resolve conflicts, there are several related terms, such as 1) conflict prevention; this pattern aims to prevent the emergence of violence in conflict, 2) conflict resolution; aimed at ending violence through peace agreements.

The form of local wisdom owned by an area will be different from other regions according to the situation at hand. Specific environmental conditions will cause differences in one's knowledge in understanding the influence of the environment on his life[10]. Local wisdom is a product of the past that deserves to be constantly held alive. Although it is a local value, the value it contains is considered universal[11].

The emergence of cases of social conflict in Indonesia is suspected because of the failure of the Indonesian people in building social interaction. This failure is because the Indonesian nation is a very diverse country in terms of ethnicity, religion, language, and culture. The background of diversity creates the potential for conflict that can lead to waning local wisdom values in the form of social capital. Seeing that reality, developing local wisdom into social capital can be used as an alternative solution to resolve social conflicts in Indonesia. Why does social capital can be an effective solution to overcome and prevent social conflict in Indonesia?

\subsection{Social Capital and Local Wisdom in Conflict Management}

The use of social capital as a solution to prevent or overcome conflicts can work well if it is supported by multiculturalism. Multiculturalism offers an important contribution to develop social capital because it analyzes the reality of cultural diversity in Indonesia. Also, social capital can be carried out thoroughly if there is a community willingness to recognize diversity. In contrast, the lack of recognition of the diversity that surrounds the life of the nation and state can result in social capital not being able to grow properly as a form of empathy and the basis of tolerance in society. Furthermore, Teezzi, Marchettini, and Rosini (2002) stated that proverb is internalized in everyday life and has the potential to become a culture, including local wisdom. This potential of local wisdom can be used as a conflict resolution for cases of conflict of beliefs in religion.

\section{CONCLUSION}

The people of Kalirejo Village maintain the harmony of religious life by respecting interfaith differences, implementing harmony, cooperation, and tolerance. On the other hand, strategies taken to anticipate conflicts in society are by building social relations between different religious and ethnic groups, managing conflict based on local wisdom, and conducting various social harmony activities by involving parties in conflict to be able to work together.

\section{ACKNOWLEDGMENTS}

This research was funded by Lembaga Penelitian dan Pengabdian kepada Masyarakat (LPPM) Universitas Negeri Semarang, Indonesia.

\section{REFERENCES}

[1] Omisore, Bernard O. Organizational Conflicts: Causes, Effects and Remedies. International Journal of Academic Research in Economics and Management Sciences. Vol 3(6):118-137. (2014).

[2] Olanrewaju, Peter, I., dan Loromeke, R. E. Multiculturalism. Value Differences and Cross Cultural Conflict in Nigeria: Surgery on a Centenarian. Journal of African Union Studies (JoAUS). Vol 6(1): 39-62 (2017).

[3] Suryanto \& Aniputra, M. G. B. Model Penyelesaian Konflik Nelayan di Selat Madura Berbasis Pada 
Kearifan Lokal Sebagai Modal Sosial. Laporan Penelitian, Surabaya: LPPM Unair. (2012).

[4] Widiyowati, E., Kriyantono, R., \& Dwi Prasetyo, B. Model Manajemen Konflik Berbasis Kearifan Lokal: Konflik Perguruan Pencak Silat Di Madiun - Jawa Timur. Komunikator, 10(1), 34-47. https://doi.org/10.18196/jkm.101004. (2018).

[5] Susan, N. Pengantar Sosiologi Konflik dan Isu-isu Konflik Kontemporer. Jakarta: Kencana. (2010).

[6] Zuhdan, M. Manajemen Konflik Berbasis Komunitas Studi Kasus Community Oriented Policing (COP) di Malioboro Yogyakarta •. Jurnal Ilmu Sosial Dan Ilmu Politik, 17(2), 130-143. (2013).

[7] Ridwan, N. A. Landasan Keilmuan Kearifan Lokal. Ibd, Vol. 5, No. 1, H. 31. (2007).

[8] Dharmawan, A.H. Konflik Sosial Dan Resolusi Konflik: Analisis Sosio-Budaya (dengan fokus Kalimantan Barat). Dalam: Seminar dan Lokakarya Nasional Pengembangan Perkebunan Wilayah Perbatasan Kalimantan, 10-11 Januari 2006, Pontianak. (2006).

[9] Sriyanto, A. Penyelesaian Konflik Berbasis Kebudayaan Lokal. Jurnal Studi Islam dan Budaya 5 (2):286-301. (2007).

[10] Kurniasari, N \& Reswati, E. Kearifan Lokal Masyarakat Lamalera: Sebuah Ekspresi Hubungan Manusia Dengan Laut. Buletin Riset Sosek Kelautan dan Perikanan 6 (2): 17- 26.(2011).

[11] Sartini. Menggali Kearifan Lokal Nusantara: Sebuah Kajian Filsafati. Jurnal Filsafat Fakultas Filsafat Universitas Gajah Mada 37 (2):21-34. (2004)

[12] Fukuyama, F. Trust: The Social Virtues and the Creation of Prosperity. NY: Free Press. (1995) 